Received: 26-01-2021

(Date-Month-Year)
Revised: 25-04-2021

(Date-Month-Year)
Published: 30-04-2021

(Date-Month-Year)

\title{
STUDENTS' THINKING PROCESSES IN SOLVING OPEN-ENDED PROBLEMS USING ONLINE LEARNING TAKING INTO ACCOUNT THE MATHEMATICAL ABILITY
}

\author{
Tigas Laila Nurpratiwi ${ }^{1}$, Rini Setianingsih ${ }^{2}$ \\ ${ }^{1}$ Pendidikan Matematika, Universitas Negeri Surabaya \\ ${ }^{2}$ Pendidikan Matematika, Universitas Negeri Surabaya \\ ${ }^{1}$ tigas.17030174005@mhs.unesa.ac.id \\ 2rinisetianingsih@unesa.ac.id
}

\begin{abstract}
It is important for a student to be able to solve problems. This study aims to describe students' thinking processes in solving open-ended problems with online learning reviewed from mathematical abilities. This research is descriptive in nature with a qualitative approach. The subjects of this research consist of three $8^{\text {th }}$ grade students, while the research instruments that were used consist of a mathematical ability test, an open-ended problem test and interview guideline. The results of the study reveal that student with high mathematical abilities meets all indicators of thinking processes, while student with average mathematical ability at the step of understanding the problem, did not carry out of making arguments, at the step of devising a plan he did not carry out the considering thinking process, as well as did not give an argument at the step of looking back. Almost the same as these results, student with low mathematical ability did not carry out the thinking process of remembering and the process of considering, while at the step of looking back, he did not carry out the process of considering and making an argument. Based on these results, it can be concluded that mathematical ability affects a student's thinking process. For further research should be conduct their research with varied subjects and use another types of mathematics problem.
\end{abstract}

Keywords: Mathematical ability; open-ended; solving a problem; thinking processes.

\begin{abstract}
Abstrak : Kemampuan dalam menyelesaikan masalah adalah hal yang penting. Tujuan dari penelitian ini adalah untuk mendeskripsikan proses berpikir siswa dalam menyelesaikan masalah open-ended dengan pembelajaran daring ditinjau dari kemampuan matematika. Subjek penelitian ini adalah tiga siswa kelas delapan. Instrument yang digunakan pada penelitian ini adalah tes kemampuan matematika, tes proses berpikir open-ended, dan pedoman wawancara. Hasil dari penelitian ini adalah siswa dengan kemampuan matematika tinggi memenuhi sетиa indikator proses berpikir. Siswa dengan kemampuan matematika sedang pada tahapan memahami masalah tidak melakukan proses berpikir membuat argumen, pada merencanakan penyelesaian tidak melakukan proses berpikir mempertimbangkan, pada saat memeriksa kembali tidak melakukan proses berpikir membuat argumen. Siswa kemampuan matematika rendah pada tahapan memahami masalah tidak melakukan proses berpikir mengingat, pada tahap merencanakan penyelesaian tidak melakukan proses berpikir pertimbangan, dan pada tahap memeriksa hasil tidak melakukan proses berpiki mempertimbangkan dan membuat argumen. Hasil tersebut menunjukkan bahwa kemampuan matematik siswa mempengaruhi proses berpikir siswa dalam menyelesaikan masalah openended.Untuk penelitian lebih lanjut dapat digunakan subjek yang bervariasi dan menggunakan tipe soal matematika yang lain.
\end{abstract}

Kata Kunci: Open-ended; kemampuan matematika; penyelesaian masalah; proses berpikir.

\section{Introduction}

Pi: Mathematics Education Journal

http://ejournal.unikama.ac.id/index.php/pmej 
Covid-19 pandemic has been attacking the world, including Indonesia, since the end of 2019. In Indonesia, the number of covid-19 positive patients per Saturday (10/07), increased to 72.347 . The entire activity of human life is disrupted by the covid-19. One of the activities that affected by covid-19 is educational activity. Educational activity very intimate with interaction that involve many people, among them is interaction between educators with learner in directly face to face learning environment (Hewi and Asnawati, 2020). The unavoidable interaction at school resulting in disruption of make educational activities by covid-19 pandemic.

With the risk of students that exposed by covid-19, the study in covid19 pandemic era could not be done in direct learning, but it has to be done with online learning. According to Moore, Dickson-Deane \& Galyen (2011) as quoted by Firman \& Rahayu (2020), online learning can be defined as teaching processes that uses internet networks as a tools and it can make various type of learning interaction. Surat Keterangan Bebas (SKB) 4 (four) ministries about new year's academic studies 2020/2021 states that the learning processes at pandemic era was not entirely done by direct learning (Kemendikbud, 2020). The result is not only face to face that meets the current conditions, so that there are some learning methods that can be optimized.

Firman \& Rahayu (2020) state that the use of internet is one of alternative in traditional learning, using internet can alter the way of knowledge transfer. Online learning using internet and multimedia technology result learning models that are normally applied by teacher cannot be optimally applied, so that the learning processes is done with assignment and question. Although the learning processes using assignment and question, the purpose of learning must be achieved, so the student must be encouraged to think in order to be able to understand the material that being taught using assignment and question learning.

In assignment and question learning, students perform thinking processes so that student can finally know the answer of the question that had been given. In studying mathematics, students not only learn about how to count a number but also learn about processes in solving mathematical problems. Students need thinking processes to bring up the idea when solving mathematics problem.

Wibowo (2016) states that thinking is an activity that produce an idea or thoughts that will be expressed verbally, written, or by gesture. The processes that take place in learning activities involve mental processes that take place in a student's brain. It can be said that learning is activities that can always be associated with thinking process.

When a student thinks, there are thinking processes in such a way that he or she finally know the answer of the assignments that are given. Setianingsih (2013) stated that in student's brain there are thinking processes until the student can answer the problems. Thinking is manipulating and transforming information in memory. When a student thinks, he or she would conceptualize, reason, critique, decide, create and solve problems (Santrock 2018).

In thinking process, people will arrange the relationship between information sections that record as understanding or knowledge, then they were summarized. Alwi (2014) stated that thinking process was a series of individual activities that occur internally when solving a problem, including 
remembering, considering, making arguments, and making decision. Thinking is always connected with issues or problems that arise.

$$
\text { According to Polya (1973) }
$$
problem solving means trying to find a way to out of the trouble, and achieving goals that are not immediately attainable. Then, according to Hamzah (2013), problem solving is a bridge between what is known and what is questioned in a problem that is faced. Polya (1973) also stated that there were four steps to solve a problem, namely, understanding the problem, devising a plan, carrying out the plan, and looking back at the completed solution. Learning processes that promote problem solving skills emphasize more than learning material. It would present a problem that guide students in problem solving processes (Fathani, 2020).

Students should be viewed as active recipients rather than passive recipients. Open-ended problem is a mathematics problem that has more than one solutions. According to Handayani et al (2018), open-ended problems will triggers the way the student thinks because with many ways that student acquires, he/she has many ways to solve mathematics problem, then in turn it will make the students more creative. Parallel to this statement, Ayu (2020) also stated that open-ended problems can make students thinking processes varied, because with open-ended problem, students will be trained to solve mathematical problem with the thought that they have.

According to Hartiningrum et al., (2020), the open aspect in open-ended problem can be classified as (1) open in solving processes, so the problems will have various solution. (2) open in their end result, so the problem will have various result. (3) open in development, it mean that when students done solve the problem, then students can develop the new problem with change the condition in the problem that had solved. In this research will be used open in solving processes and open in their end result. The student's ability to solve a problems is affected by several factors such us (1) early experiences (2) background, (3) desire and motivation and (4) problem structure (Siswono 2018). In this research use student's mathematical ability overview, and it was contained in the background section.

Mathematical ability is defined as skills in executing or finishing mathematical task (Sumarmo, 2010). The counting processes is simplest math activity, while the complex one is proving. It can be said that mathematical ability is the skill to finish a task and manipulate a number effectively. The ability to work with numbers use an idea that related to numbers is called mathematics ability (Nizoloman, 2013).

In solving mathematics problem, every student has different ways and thinking styles. Mathematical ability is an important factor in student's thinking processes in solving open-ended mathematical problems. According to Siswono (2008) students who have different backgrounds and mathematical abilities, also have different thinking processes in solving various mathematical problem. Mathematical ability can be classified as high, average, and low mathematical abilities (Lailiyah \& Lestariningsih, 2018).

$$
\begin{aligned}
& \text { According to } \begin{array}{r}
\text { Permendikbud } \\
\text { No.23 (2016), the rinimum }
\end{array} \\
& \text { completeness criteria (KKM, Kriteria }
\end{aligned}
$$
Ketuntasan Minimal) is determined by each educational unit. At this research the minimum completeness criteria is 75 .

As discussed in the research background about the important of student's thinking skill to solve

Pi: Mathematics Education Journal 
mathematical problem, it is suggested for a teacher to know the process of student's thinking in solving mathematics problem for better learning processes. Students thinking process was researched with a various types, in previous research the subject was used direct learning, but in this research using online learning with open ended problems and based on mathematical ability. Therefore, the research question that will be answered in this study is how does the student's thinking processes in solving open-ended problem with online learning taking into account the mathematical ability.

\section{Research Method}

This study is a descriptive in nature with a qualitative approach. The purpose of this study is to describe the student's thinking processes in solving open-ended problems with online learning based on mathematical abilities. As the main instrument of this research is the researcher herself, while the supporting instruments consist of mathematical ability test, thinking processes test using open-ended problem, and interview guidelines.

The research was conducted at grade VIII at one of Junior High School in Tuban. The research subjects were selected by giving a test of mathematical ability to all students of class VIII-A after they had finished learning mathematics material. By considering the result of mathematical ability test, then the students' work was categorized by using the references in Tabel 1.

Tabel 1. Category of Students' Mathematical Ability.

\begin{tabular}{ll}
\hline \multicolumn{1}{c}{$\begin{array}{c}\text { Students' } \\
\text { Mathematical ability }\end{array}$} & \multicolumn{1}{c}{ Score Intervals } \\
\hline $\begin{array}{l}\text { High mathematical } \\
\text { ability }\end{array}$ & $85 \leq$ student's score $\leq$ \\
\hline Average mathematical & 100 \\
ability & $75 \leq$ student's score \\
\hline
\end{tabular}

\begin{tabular}{ll}
\hline Low mathematical & $0 \leq$ student's score \\
ability & $<75$ \\
\hline
\end{tabular}

In turn, the researcher selected 1 (one) student for each category (high, average, low) mathematical abilities. In addition, the researcher also considered the optimal difference of student's score, and their ability in communicating with others, as well as of the same gender.

Then, the three subjects were given an open-ended test, to obtain the data of the student's thinking processes in solving open-ended problems. To obtain the more detail information related to students' thinking processes in solving open-ended problems, the three subjects were interviewed alternately.

The data obtain from this test were then analyzed using the thinking process indicators adapted from Alwi (2014). In is important to state that in this research, when a subject fulfills one of the thinking process indicators, it means that he undergoes the stage of such thinking process.

\section{Result and Discussion}

1. Mathematical Thinking Processes of Students with High Mathematics Ability in Solving Open-ended Problems through Online Learning.
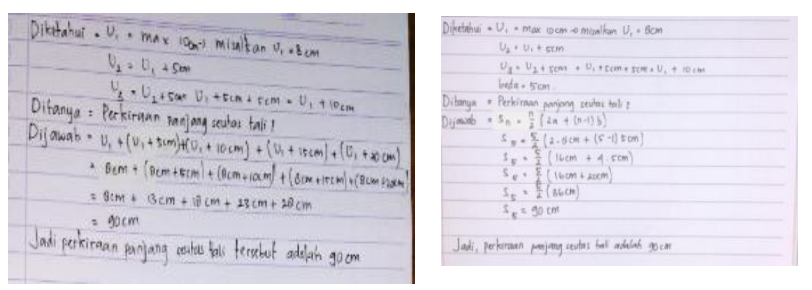

Figure1. Student's Work for Problem 1.

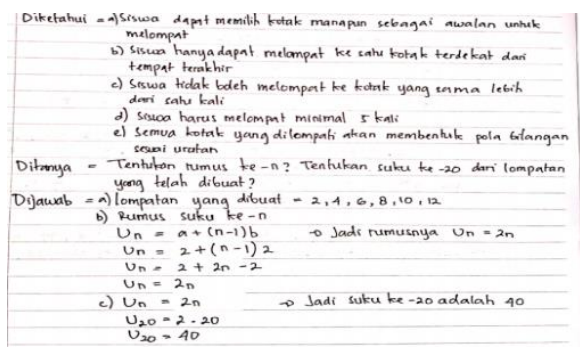

Pi: Mathematics Education Journal 
Figure 2. Student's Work for Problem 2.

In the step of understanding the problem, the student with high mathematical ability was asked to identify problem by reading it. During the reading process, a series of information were obtained automatically by student, which were then processed into knowledge and creative abilities for students. This is in agreement with Slavin's opinion (2006) which regarded such a skill at the time of processing information. It also indicates that the student has successfully obtained certain information from the environment to be processed into a science.

Subsequently, she wrote down the important things that had been identified and generated some questions that need to be asked. In the step of writing and generating questions in connection with his identification results, it is revealed that student with high mathematical ability had succeeded in carrying out the thinking processes in terms of remembering. This is in accordance with Slavin (2006) information processing theory, which regarded that the processes of recalling information shows the ability to remember information that has been successfully received and also the ability to reveal previous knowledge. In addition, through the process of writing various things that had been identified and asked, student with high mathematical ability was able to explain the information relations that had been identified and asked previously, so that it can be said that she could apply the thinking process in terms of argument preparation.

Furthermore, student with high mathematics ability stated that the information she had provided was able to be used in solving problem. It means that she was able to apply the thinking process in terms of decision making.

In planning the problem-solving, student with high mathematical ability had remembered all the problems they had encountered. Moreover, she had also been able to recall properly the formulae and concepts that had been used previously. This indicated that she had succeeded in carrying out the thinking process in terms of remembering. In addition, she had also been able to take consideration of various possibilities that lead to problem-solving. This showed that students with high mathematical ability had succeeded in applying the thinking processes in terms of consideration. This is in connection with the statement of Sternberg (2008), which explained that humans in reaching reasonable decisions are largely determined by five important factors, one of which is to consider all known alternatives.

After applying the consideration process, student with high mathematical ability determined the most appropriate steps to use. Regarding to this matter, she was able to apply the thinking processes in terms of decision making.

Then, after determining the decision regarding to the planning of the problem-solving, she carried out the problem-solving plan with the following steps. First, she wrote formulae and concepts according to the plan. At the time of the writing process, she did the thinking process in terms of remembering. This is consistent with the claim of Isroil et.al (2017) who revealed that at the time of implementing the problem-solving plan, students recall the information related to the steps that are determined at the stage of planning the problem-solving.

Furthermore, student with high mathematical ability determined the 
easiest step to apply the plans that had been made. It means that she was able to apply the thinking process in terms of consideration. She was also able to describe in detail how to apply the problem-solving processes in accordance with the specified plan, and then decided to generate solutions of the problem. Referring to that matter, she was able to apply the thinking processes in terms of making arguments and making decisions.

After determining the decision, students with high mathematics ability checked the problem-solving process that had been carried out. When checking the results, she could recall the previous problem-solving steps. This showed that she was able to apply the thinking process in terms of remembering.

Besides, she also checked whether there was an error in carrying out the problem-solving plan. At this stage, it can be seen that she had successed in applying the thinking processes in terms of consideration she also believed that the final answer she obtained was correct, and then she provided reasons related to their belief in the answer. Referring to that matter, the researcher concluded that student with high mathematical ability was able to carry out the thinking process in terms of making arguments and making decisions.

2. Mathematical Thinking Processes of Students with Average Mathematics Ability in Solving Open-ended Problems through Online Learning.

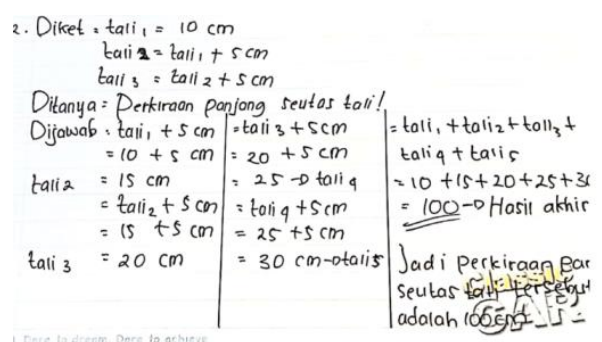

Figure 3. Student's Solution on Problem 1.

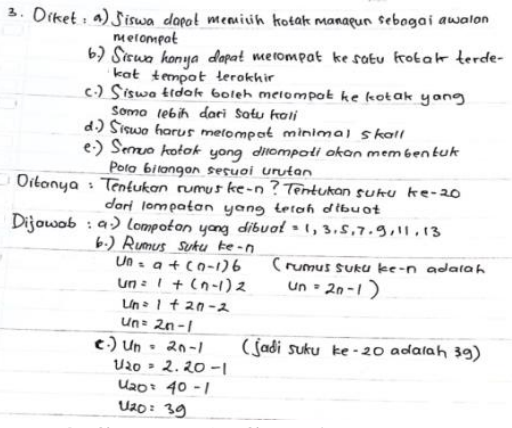

Figure 4. Student's Solution on Problem 2.

At the initial stage, student with average mathematics ability identified the problems given through reading process, in which she clearly received the information of the problem. This is in agreement with Slavin (2006) who regarded that at the time of processing information, the information will be immediately obtained by student, and this indicates that the student has successfully obtained certain information from the environment to be processed into a science. After carrying out the process of understanding the problems, she wrote down the important things that had been identified before, and generated some questions that need to be asked. In the act of writing and generating questions in connection with their identification results, it revealed that she succeeded in carrying out the thinking processes in terms of remembering.

This student was also able to explain that there was a relationship between information that was known, and information that needs to be asked. However, she was completely unaware of this relation. Referring to that matter, she was not able to compose arguments and was not able to carry out the thinking processes in terms of making arguments.

Besides, she stated that the information provided to him could be used to implement the problem-solving stage. It means that she was able to carry out the thinking processes in terms of decision making.

Pi: Mathematics Education Journal 
She had never encountered problems such as the problems given, but she was able to partially remember the formulae that can be used to solve problems. It implied that she was able to carry out the thinking process in terms of remembering. This is in line with the opinion of Isroil et.al (2017) that subjects with average mathematical abilities is able to link the previous knowledge.

During the process of implementing the problem-solving, she was only able to think about one idea that had been written, but she was unable to develop other ideas, so it can be said that she was not able to consider the various possibilities that lead to the problemsolving process, but rather directly made decisions. Referring to that matter, it can be said that she was not able to apply the thinking process in terms of consideration, but she was able to carry out the thinking process in terms of decision making.

After determining the decision regarding to the planning of the problemsolving, then she carried out the problemsolving plan. At the initial stage, she wrote formulae and concepts according to the plan. At the time of the writing processes, she did the thinking processes in terms of remembering. This is consistent with the opinion of Isroil et.al (2017) who revealed that at the time of implementing the problem-solving plan, students recall the information related to the steps that are determined at the stage of planning the problem-solving. Then, she determined the easiest step to apply the plans that had been written. It can be stated that she was able to apply the thinking process in terms of consideration.

The student with average mathematics ability was able to describe in detail how to apply the problemsolving process such that she was able to carry out the thinking process in terms of making arguments. She was also able to find the final result of the given problem, so that the thinking processes was aroused in terms of decision making.

After the final results had been obtained, she then checked the problemsolving processes that had been written. When checking the results, she remembered the previous problemsolving steps, which indicated that she was able to apply the thinking process in terms of remembering.

This student also stated that there were no errors in the problem-solving process that had been applied. It means that she was able to apply the thinking process in terms of consideration. After the process of consideration, then she believed that her final solution was correct. This in turn made her able to carry out the thinking process in terms of decision making, but the student was not able to conduct the thinking process in terms of making arguments, because she was not able to clearly explain the reasons for believing the process of problem-solving that was applied.

3. Mathematical Thinking Processes of Students with Low Mathematics Ability in Solving Open-ended Problems through Online Learning.

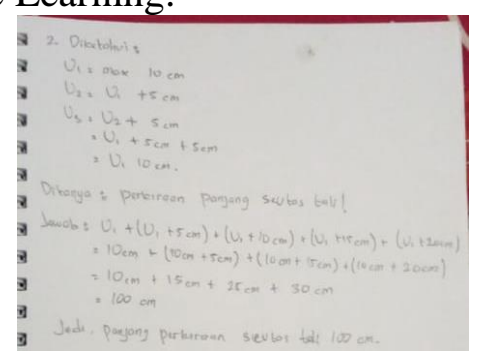

Figure 5. Student's Solution on Problem 1.

Pi: Mathematics Education Journal

http://ejournal.unikama.ac.id/index.php/pmej 


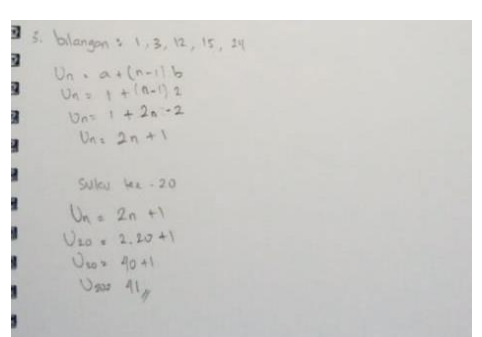

Figure 6. Student's Solution on Problem 2.

In building an understanding of problems, student with low mathematics ability was required to be able to identify problems by reading them. However, she was confused to write down the information that had been identified and develop questions that need to be asked, so that she was not able to apply the thinking processes in terms of remembering. Furthermore, the student with low mathematics ability was confused to explain further about the relationship that arises between the information that had been identified and the questions that need to be asked, so that she was not able to carry out the thinking processes in terms of making arguments. In addition, student with low mathematics ability stated that the provided information was able to be used in solving problems, so that she was able to apply the thinking processes in terms of decision making.

After understanding the problem, student with low mathematics ability had remembered all the relevant problems and the formulae associated with the problem. This indicated she had succeeded in carrying out the thinking processes in terms of remembering. This is in agreement with Slavin (2006) who regarded that the processes of recalling information shows the ability to remember information that has been successfully received and also the ability to reveal previous knowledge. During the processes of implementing the problemsolving, student with low mathematics ability was not able to develop other ideas to solve the problem, so she immediately determined only one idea. This caused student with low mathematics ability to be unable to carry out the thinking processes in terms of consideration, but she was able to carry out the thinking processes in terms of making decisions.

After determining the decision regarding to the planning of the problemsolving, then she carried out the problemsolving plan. At the initial stage, she wrote formulae according to the plan. At the time of the writing the formulae, she did the thinking processes in terms of remembering. In planning the problemsolving, student with low mathematics ability determined the easiest step to apply the plans that had been written. Therefore, she was able to apply the thinking processes in terms of consideration. Moreover, she was able to describe in detail how to apply the problem-solving processes so that she was able to carry out the thinking processes in terms of making arguments. Furthermore, student with low mathematics ability had carried out the thinking processes in terms of making decisions by writing the final result at the stage of applying the problem-solving plan.

After the final results had been obtained, student with low mathematics ability checked the problem-solving processes that had been written. When checking the results, she had already remembered the previous problemsolving steps, which indicated that she was able to apply the thinking processes in terms of remembering.

Furthermore, student with low mathematics ability stated that there was no errors in the problem-solving processes that had been applied. However, there were some incorrect steps, so that she was not able to apply 
the thinking processes in terms of consideration. This is in accordance with the opinion of Engle (1990) which stated that knowledge is considered an important factor in increasing knowledge.

Furthermore, student with low mathematics ability had believed that her solution was correct, but she did not provide any reason for the answers that had been obtained, so it can be concluded that student with low mathematics ability was able to carry out the thinking process in terms of making decisions, but she was not able to carry out the thinking process in terms of making arguments.

\section{Conclusion}

Based on the result and discussion at this research, it can be concluded that students' thinking processes in solving open-ended problem taking into account the mathematical ability can be described as follows.

Student with high mathematical ability, at the step of understanding the problem, is able to carry out the thinking processes of term remembering, making argument, and making decision. At the step of devising a plan, she is able to carry out the thinking processes of term remembering, considering, and making decisions. Moreover, at the step of carrying out the plan, the student is able to carry out the thinking processes in term remembering, making arguments, and making decision. At the step of looking back at the completed solution, the student is able to carry out the thinking processes in term remembering, considering, making arguments, and making decisions.

Student with average mathematical ability, at the step of understanding the problem, is able to carry out the thinking processes in term remembering, and making decisions. At the step of devising a plan, she is able to carry out the thinking processes in term remembering and making decisions. At the step of carrying out the plan, the student is able to carry out the thinking processes in terms of remembering, considering, and making decision. Then, at the step of looking back at complete solution step, the student is able to carry out the thinking processes in terms of remembering, considering, and making decisions.

Student with low mathematical ability, at the step of understanding the problem, is able to carry out the thinking processes in terms of making decision, while at the step of devising a plan, she is able to carry out the thinking processes in terms of remembering, and making decisions. Then, at the step of carrying out the plan, she is able to carry out the thinking processes in terms of remembering, considering, making argument, and making decision. Finally, at the step of looking back at complete solution, she is able to carry out the thinking processes in terms of remembering and making decision.

Considering the explanation above, it can be concluded that there are some differences in students' thinking processes taking into account the mathematical ability. It implied that mathematical ability affects the students' thinking processes in solving problems.

Based on the results of this study, the researchers suggest that for the other researcher who might interest in conducting similar research, to have various types of subjects, because in this research the subject is only female. Then for other researcher who had online test it should be using different questions with the same standard.

\section{Acknowledgements}

The researcher realizes that the success of this article is inseparable from help and support of various parties. 
Therefore, on this occasion the researcher would like to express her gratitude to:

1. Ibu Dr. Rini Setianingsih, M.Kes., as supervisor of this research.

2. The headmaster of SMP Negeri 1 Jatirogo that was allowed the researcher to collect the data at SMP Negeri 1 Jatirogo, Tuban.

\section{References}

Ahmadi, H.A. 2009. Psikologi Umum. Jakarta: Rineka Cipta.

Alwi. 2014. Proses Berpikir Siswa SMP dalam Menyelesaikan Masalah Kesebangunan Bangun Datar Ditinjau dari Perbedaan Kemampuan Matematika. Surabaya: Universitas Negeri Surabaya

Ayu, L.S., Moharom, M.I., Zanthy, L. 2020. Analisis Kemampuan Berpikir Kreatif Matematis Siswa SMP dalam Menyelesaikan Soal Adopsi 'PISA'. Jurnal Math Educator Nusantara: Wahana Publikasi Karya Tulis Ilmiah Di Bidang Pendidikan Matematika, 7(1): 8-17.

Engle, R. W., Nations, J. K., \& Cantor, J. 1990. Working Memory Capacity Just Another Name for Word Knowledge. Journal of Educational Psychology, 82(4): 799-804.

Fathani, A.H, Ismi, Yuli, I, Nahdiyati, S, Firul. 2020. Penerapan Group Investigation Untuk Meningkatkan Kemampuan Pemecahan Masalah Kontekstual Bagi Peserta Didik Kelas X SMA Islam Nusantara Malang. Jurnal Edukasi dan Sains Matematika, 6(1): 1-10.

Firman \& Rahayu, S. 2020. Pembelajaran Online di Tengah Pandemi Covid19. Indonesian Journal of Educational Science (IJES), 2(2): 81-89.

Hamzah, A. dan Muhlisrarini. 2013. Perencanaan dan Strategi Pembelajaran Matematika. Jakarta:
PT Raja Grafindo Persada.

Handayani, Fitri, U., Sa'dijah, C. \& Susanto, H. 2018. Analisis Kemampuan Berpikir Kreatif Matematis Siswa SMP dalam Menyelesaikan Soal Adopsi 'PISA'. Jurnal Math Educator Nusantara: Wahana Publikasi Karya Tulis Ilmiah di Bidang Pendidikan Matematika, 4(2):143.

Hartiningrum, Nur, E.S., Maarif, S., \& Wijayanti, A. 2020. Profil Kreativitas Siswa Feminin dalam Menyelesaikan Soal Cerita Matematika Open-ended Berdasarkan Kemampuan Matematika. Jurnal Ilmiah Soulmath: Jurnal Edukasi Pendidikan Matematika, 8(1): 45.

Hewi, L, and Asnawati, L. 2020. Strategi Pendidik Anak Usia Dini Era Covid19 dalam Menumbuhkan Kemampuan Berpikir Logis. Jurnal Obsesi: Jurnal Pendidikan Anak Usia Dini, 5(1):158.

Isroil, A., Budayasa, I. K. \& Masriyah. 2017. Profil Berpikir Siswa SMP dalam Menyelesaikan Masalah Matematika Ditinjau dari Kemampuan Matematika. Jurnal Review Pembelajaran Matematika, 2(2): 93-105.

Kemendikbud. 2020. Kementerian Pendidikan dan Kebudayaan » Republik Indonesia. Retrieved July 9,

2020. (https://www.kemdikbud.go.id/main /blog/2020/06/panduanpenyelenggaraan-pembelajaranpada-tahun-ajaran-dan-tahunakademik-baru-di-masa-covid19).

Lailiyah, E.F. \& Lestariningsih. 2018. Profil Proses Berpikir Siswa dalam Pengajuan Soal (Problem Posing) Ditinjau dari Kemampuan Matematika. Jurnal Pendidikan Matematika RAFA, 4(1): 43-52. 
Nizoloman, O.N. 2013. Relationship between Mathematical Ability and Achievement in Mathematics among Female Secondary School Students in Bayelsa State Nigeria. Procedia Social and Behavioral Sciences 106:2230-40.

Polya, G. 1973. How to Solve It (A New Aspect of Mathematical Method). New Jersey: Princeton University Press.

Santrock, J.W. 2018. Educational Psychology; $6^{\text {th }}$ Edition. New York: McGraw-Hill Companies.

Setianingsih, R. 2013. "Proses Berpikir Siswa dengan Kecerdasan Linguistik dan Logis Matematis dalam Memecahkan Masalah Matematika." Jurnal Mathedunesa, 3(2):1-8.

Siswono, T. Y. E. 2008. Model Pembelajaran Matematika Berbasis Pengajuan dan Pemecahan Masalah untuk Meningkatkan Kemampuan Berpikir Kreatif. Surabaya: Unesa University Press.

Siswono, T. Y. E. 2018. Pembelajaran Matematika Berbasis Pengajuan dan Pemecahan Masalah. Bandung: Remaja Rosdakarya.

Slavin, R. E. 2006. Educational Psychology: Theory and Practice ( $8^{\text {th }}$ Edition). Boston: Pearson Education, Inc.

Sternberg, R.J. 2008. Psikologi Kognitif. Edisi Kedelapan. Edisi Bahasa Indonesia. Penerjemah: Yudi Santoso, S.Fil. Yogyakarta: Pustaka Pelajar.

Sumarmo, U. 2010. Berpikir dan Disposisi Matematik: Apa, Mengapa, dan Bagaimana Dikembangkan pada Peserta Didik. FPMIPA UPI 1-27.

Wibowo, K. 2016. Defragmenting Struktur Berpikir Pseudo dalam Memecahkan Masalah Matematika. Yogyakarta: Deepublish. 